\title{
STUDI TENTANG HASIL BELAJAR PKn SISWA KELAS XI SMAN 2 WOHA BIMA MENGGUNAKAN MODEL PEMBELAJARAN INKUIRI TERBIMBING DENGAN MODEL PEMBELAJARAN INKUIRI TRAINING TAHUN PELAJARAN 2016/2017
}

\author{
Drs. H. M. Yunan HS, M.Pd \& Ayu Pratiwi \\ (Dosen PNS DPK Kopertis VIII Nusra)
}

\section{INFO ARTIKEL}

\section{Riwayat Artikel:}

Diterima: 01-03-2016

Disetujui: $30-03-2016$

Kata Kunci: Model
Pembelajaran Inkuiri
Terbimbing, Model Inkuri
training, Hasil Belajar.

ABSTRAK

Abstrak: Penelitian ini merupakan penelitian kuantitatif dengan menggunakan pendekatan eksperimen dalam bentuk quasi eksperimen. Berdasarkan hipotesis yang diajukan peneliti, untuk melakukan penelitian terhadap yang diajukan peneliti, peneiti menggunakan pendekatan quasi eksperimen dengan desain non randomize pretes-posttest control group.

Tujuan penelitian ini adalah untuk mengetahui Studi tentang hasil belajar PKn siswa kelas XI SMAN 2 WOHA Bima menggunakan model pembelajaran inkuiri terbimbing dengan model pembelajaran inkuiri training Tahun pelajaran 2016/2017, Populasi dalam penelitian ini adalah semua siswa kelas XI SMAN 2 Woha. Sampel penelitian diambil dengan teknik simple random sampling dengan cara undian, kelas XI IPA 2 ditentukan sebagai eksperimen dan kelas XI IPA 3 sebagai kelas kontrol. Instrumen yang digunakan berupa tes objektif dalam bentuk pilihan ganda yang telah diuji kelayakannya sebanyak 30 soal, terdapat 20 soal yang valid, dimana 20 soal pre-test dan 20 soal post-test yang telah diuji kelayakkannya.

Teknik analisis data digunakan uji persyaratan analisis yang meliputi uji homogenitas dan uji normalitas, sedangkan uji hipotesis yang digunakan adalah uji $t$-tes. Berdasarkan hasil perhitungan uji normalitas post-test data diperoleh $x^{2}$ hitung $=5,144$ dan $x^{2}$ tabel $=11,070$ dengan $x_{\text {hitung }}^{2} 5.144$ dan $x_{\text {tabel }}^{2}=11.070$. Karena $x^{2}$ hitung $<x^{2}$ tabel maka kedua sampel berdistribusi normal pada taraf signifikan 5\%. Berdasarkan hasil perhitungan uji homogenitas post-test data diperoleh $f_{\text {hitung }}=1.24$ dan $f_{\text {tabel }}=2,04$. Karena $f_{\text {hitung }}<f_{\text {tabel }}$ maka varians kedua sampel homogen. Pada uji hipotesis uji $t$-tes diperoleh nilai post-test $t_{\text {hitung }}=14.559$ dan $t_{\text {tebel }}=2,000\left(t_{\text {hitung }}>t_{\text {tebel }}\right)$ dengan $t_{\text {hitung }}=14.559$ dan $t_{\text {tebel }}=2,000$ yang menunjukan hipotesis nol $(\mathrm{Ho})$ ditolak dan hipotesis alternatif $(\mathrm{Ha})$ diterima, sehingga terdapat perbedaan. Penelitian ini dapat disimpulkan bahwa ada Perbedaan Studi tentang hasil belajar pkn siswa kelas XI SMAN 2 WOHA Bima menggunakan model pembelajaran inkuiri terbimbing dengan model pembelajaran inkuiri training Tahun pelajaran 2016/2017.
Abstract: This research represent quantitative research by using approach of experiment in the form of experiment quasi. Pursuant to raised by hypothesis is researcher, to conduct research to which is raised by researcher, researcher use approach of experiment quasi with desain of non group control pretes-posttest randomize.

Target of this research is to know Influence Between Model Study Of Inkuiri Guided With Model Study Of Inkuiri Training To Result Learn PKn Student Class of XI SMAN 2 Woha School Year 2016/2017. Population in this research is all class student of XI SMAN 2 Woha. Research Sampel taken with technique of simple sampling random by toss, class of XI IPA 2 determined as class experiment and class of XI IPA 3 as control class. used instrument in the form of objective tes in the form of double helix which have been tested by elegibility of him counted 30 problem, there are 20 valid problem, where 20 problem of pre-test and 20 problem of post-test which have been tested him.

Technique analyse data used by test conditions of analysis covering homogeneity test and test of normalitas, while hypothesis test the used is test $t$. Pursuant to result of calculation of test of normalitas data post-test obtained. $x_{\text {count }}^{2}=5,144$ and $x^{2}$ table $=11,070$ with $x^{2}$ count $=5.144$ and $x^{2}$ table $=11.070$. Because $x^{2}$ count $<x^{2}$ table hence both sampel have normal distribution to at level of signifikan $5 \%$. Pursuant to result of calculation of homogeneity test of post-test data obtained. $f_{\text {count }}=1.24$ and $f_{\text {table }}=2,04$. Because $f_{\text {count }}<$ $\mathrm{f}_{\text {table }}$ hence varians both of homogeneous sampel. At test hypothesis test $t$-test post-test is obtained by value $t_{\text {count }}=14.559$ and $t_{\text {teble }}=2,000$ ( $t_{\text {count }}>t_{\text {table }}$ ) with $t_{\text {count }}=14.559$ and $t_{\text {teble }}$ $=2,000$ which is hypothesis showing zero $(\mathrm{Ho})$ refused and alternative hypothesis $(\mathrm{Ha})$ accepted, so that there are difference. This research can be concluded by that there is Difference Of Influence Between Model Study Of Inkuiri Guided With Model Study Of Inkuiri Training To Result Learn PKN Student Class of XI SMAN 2 Woha School Year 2016. 


\section{A. LATAR BELAKANG}

Pembelajaran PKn bukanlah semata-mata pelajaran yang hanya mengetahui keadaan warga negara saja, akan tetapi kita perlu tahu bahwa menerapkan sikap patriotisme dan nasionalisme harus tercermin pada diri siswa itu sendiri, sehingga mempelajari PKn sangat penting bagi generasi muda, terutama pada siswa dan siswi yang duduk dibangku sekolah SD, SMP/MTs, SMA/MA dan perguruan tinggi.

Berdasarkan hasil observasi awal berupa datadata pada hasil nilai akhir semester genap tahun pelajaran 2015-2016 diperoleh nilai dengan porsentase $65 \%$ siswa yang berhasil mendapatkan nilai yang sesuai dan diatas KKM dengan kriteria ketuntasan minimal (KKM) yang ditentukan sekolah yaitu 70. Dan masih banyak siswa yang tidak tuntas dengan porsentase 35\%dengan nilai dibawah KKM.

Penerapan yang tepat untuk mengatasinya guru hendaknya menggunakan model pembelajaran Inkuiri terbimbing dan model pembelajaran inkuiri trainingagar dapat memotivasi siswa menjadi aktif dalam pembelajaran maupun aktif dalam mencari informasi dari berbagai sumber. Dengan demikian, motivasi siswa yang rendah menjadi lebih baik setelah siswa memperoleh informasi yang benar.

Berdasarkan deskripsi yang dikemukakan diatas menjadi alasan utama peneliti untuk melakukan penelitian yang berjudul "Pengaruh Antara Model PembelajaranInkuiri Terbimbing Dengan Model Pembelajaran Inkuiri Training Terhadap Hasil Belajar PKn Siswa Kelas XI SMAN 2 Woha Tahun Pelajaran 2016/2017"

\section{B. METODE PENELITIAN}

\section{Jenis Penelitian}

Penelitian ini merupakan penelitian kuantitatif dengan menggunakan pendekatan eksperimen dalam bentuk quasi eksperimen. Berdasarkan hipotesis yang diajukan peneliti, untuk melakukan penelitian terhadap hipotesis yang diajukan peneliti, peneiti menggunakan pendekatan quasi eksperimen dengan desain non randomize pretes-posttest control group dan untuk membandingkan perbedaan terhadap hipotesis yang diajukan peneliti, peneliti menggunakan studi komparatif.

Pendekatan eksperimen adalah suatu penelitian yang digunakan untuk mencari pengaruh perlakuan (treatment)tertentu terhadap yang lain dalam kondisi yang terkendalikan.Penelitian ini pada umumnya dianggap sebagai metode penelitian yang canggih dan untuk menguji hipotesis.
Quasi experimental merupakan pengembangan dari true experimental design, yang sulit dilaksanakan. Desain ini mempunyai kelompok kontrol, tetapi tidak dapat berfungsi sepenuhnya untuk mengontrol variabelvariabel luar yang mempengaruhi pelaksanaan eksperimen (Sugiyono, 2014:77).Desain Non rendomize pretes-posttestcontrol group, penelitian ini dilaksanakan disuatu kelas tertentu, dimana siswa yang telah ada sebagaimana mestinya. Dalam menetapkan kelompok eksperimen dan kontrol, hanya dilakukan secara acak terhadap kelas yang ada dengan subyek yang relatif sama seperti usia, tingkat, jumlah siswa, waktu belajar dan lain-lain. Sebelum perlakuan dilakukan (X) kedua kelompok diberikan prates, hasilnya diolah dan dibandingkan, apakah rata-rata dan simpangan bakunya berbeda secara signifikan atau tidak.

Desain penelitian menggunakan desain non randomize pretest-posttest control group. Berikut rancangan desain non randomize pretest-posttest control group adalah:

\begin{tabular}{|l|c|c|c|}
\hline Kelompok & $\begin{array}{l}\text { Pra } \\
\text { tes }\end{array}$ & $\begin{array}{c}\text { Perlakua } \\
\text { n } \\
\text { (bebas) }\end{array}$ & $\begin{array}{c}\text { Pascates } \\
\text { (terikat) }\end{array}$ \\
\hline $\begin{array}{l}\text { Ekperimen } \\
\text { Kontrol }\end{array}$ & Y1 & $\mathbf{X}$ & Y2 \\
\hline
\end{tabular}

Desain non randomize pretest-posttest control group

\section{Lokasi Dan Waktu Penelitian}

Penelitian ini dilaksanakan pada siswa kelas XI SMAN 2 Woha di Jln. Buya Hamka Kalampa, dan waktu penelitian akan dilaksanakan pada bulan juli 2016. Dalam penelitian ini populasi penelitiannya adalah siswa kelas XI SMAN 2 Woha semester ganjil tahun pelajaran 2016/2017 dengan jumlah lima (5) kelas yang terdiri dari 25-30 orang siswa dalam setiap kelas.

\section{Metode Penentuan Subjek Penelitian \\ - Populasi}

Menurut Arikunto, (2013: 130) populasi adalah keseluruhan subyek penelitian. Populasi adalah wilayah generalisasi yang terdiri atas: obyek/subyek yang mempunyai kualitas dan karakteristik tertentu yang ditetapkan oleh peneliti untuk dipelajari dan kemudian ditarik kesimpulannya

Populasi dalam penelitian ini adalah siswa kelas XI SMAN 2 Woha yang terdiri dari 5 kelas

\begin{tabular}{|c|c|c|c|c|}
\hline No & Kelas & $\begin{array}{c}\text { Jumlah } \\
\text { siswa }\end{array}$ & $\begin{array}{c}\text { Laki- } \\
\text { laki }\end{array}$ & Perempuan \\
\hline 1 & IPA 1 & $\mathbf{3 0}$ & 12 & $\mathbf{1 8}$ \\
\hline 2 & IPA 2 & $\mathbf{2 5}$ & $\mathbf{9}$ & $\mathbf{1 6}$ \\
\hline 3 & IPA 3 & $\mathbf{2 8}$ & 5 & $\mathbf{2 3}$ \\
\hline 4 & IPS 1 & $\mathbf{3 0}$ & $\mathbf{1 1}$ & $\mathbf{1 9}$ \\
\hline 5 & IPS 2 & $\mathbf{3 0}$ & $\mathbf{1 5}$ & $\mathbf{1 5}$ \\
\hline
\end{tabular}




\section{- Sampel}

Sampel adalah bagian dari jumlah dan karakteristik yang dimiliki oleh populasi tersebut. Oleh karena itu, sampel harus diambil dari populasi yang benar-benar resprentatif (Sugiyono, 2012: 80).

\section{Metode Pengumpulan Data Dan Instrumen Penelitian}

- Metode Pengumpulan Data

a. Dokumentasi

Dokumentasi adalah teknik pengumpulan data yang dilakukan dengan cara melalui berbagai dokumentasi yang ada dan diperlukan oleh peneliti, seperti nilai yang ada pada leger guru, raport, dll (Sundara, 2012:24).Teknikdokumentasi ini peneliti gunakan untuk mendapatkan data penelitian terkait dengan:

a. Data keadaan Siswa SMAN 2 Woha.

b. Data keadaan Guru, Pegawai dan Karyawan SMAN 2 Woha.

c. Struktur organisasi SMAN 2 Woha.

\section{b. Tes}

Tes dapat dikategorikan menjadi dua, yaitu tes objektif dan tes subjektif.

1) Tes objektif adalah bentuk tes yang mengandung kemungkinan jawaban atau respon yang harus dipilih oleh peserta tes. Secara umum ada tiga tipe tes objektif, yaitu: benar-salah (true-false), menjodohkan (macthing), dan pilihan ganda (multi choice).

2) Tes subjektif adalah butir soal yang mengandung pertanyaan atau tugas yang jawaban atau pengerjaan soal tersebut harus dilakukan dengan cara mengeksperisikan pikiran peserta tes (Asmawi Zaenul danNoehi Nasution dalam Widoyoko, 2014 : 115).

\section{c. Instrumen Penelitian}

Terdapat dua hal yang mempengaruhi kualitas hasil penelitian yaitu: kualitas instrumen penelitian dan pengumpulan data. Dalam penelitian kuantitatif, kualitas instrumen penelitian berkenaan dengan validitas dan reabilitas instrumen penelitian dan kualitas pengumpulan data. Instrumen dalam penelittian kuantitatif dapat berupa test, pedoman wawancara, pedoman observasi dan kuesioner (Sugiyono, 2014 : 222).

\section{d. Pengujian Validitas Isi (content validity)}

Alat ukur dikatakan valid apabila alat ukur itu dapat dengan tepat mengukur apa yang hendak diukur.

Uji validitas berupa tes digunakan rumus korelasi Produk moment. Adapun rumus tersebut sebagai berikut :

$r_{x y}=\frac{N 2 X Y-(2 X)(2 Y)}{\sqrt{\left(N \sum X^{2}-\left(\sum X\right)^{2}\right]\left[N \sum Y^{2}-\left(\sum Y\right)^{2]}\right.}}$

Keterangan :

$\mathrm{r}_{\mathrm{xy}}=$ Koefisien korelasi product moment antara variabel $\mathrm{x}$ dan $\mathrm{y}$

$\sum X_{i}=$ Jumlah skor butir soal

$\sum Y_{i}=$ Jumlah skor total

$\mathrm{N} \quad=$ Jumlah sampel

$\Sigma \mathrm{x}_{1}{ }^{2}=$ Jumlah kuadrat skor butir soal

$2 \mathrm{Y}_{1}^{2}=$ Jumlah kuadrat skor butir soal

\section{$\Sigma X_{i} Y_{i}=$ Jumlah hasil kali skor butir soal}

Arikunto (2013: 93).

Dari hasil uji validitas yang terdiri dari 30 butir soal, dimana penguji dilakukan dengan membandingkan nilai $\mathrm{r}_{\text {hitung }}$ tiap butir soal dan $\mathrm{r}_{\text {tabel. }}$. Untuk Nilai hasil uji coba validitas awal nilai pre-test dengan inilai $\mathbf{r}_{\text {tabel }}$ yang digunakan adalah nilai $\mathrm{r}$ pada taraf signifikan $5 \%$ untuk $\mathrm{N}=28$ yaitu 0,374 dengan kriteria diperoleh 20 butir soal yang valid, Setelah itu baru dibandingkan dengan harga korelasi yakni $r_{\text {hitung. }}$. Hasil pre-test dari butir soal 1 mendapatkan nilai $\mathrm{r}_{\text {hitung }}=-0,04964$ dan $\mathrm{r}_{\text {tabel }}=0,374$ kesimpulanya $\mathrm{r}_{\text {hitung }}<\mathrm{r}_{\text {tabel }}$ maka butir soal 1 dinyatakan invalid).

Dan kemudian pada hasil uji coba validitas akhir post-test dengan $\mathrm{r}_{\text {tabel }}$ yang digunakan adalah nilai $\mathrm{r}$ pada taraf signifikan $5 \%$ untuk $\mathrm{N}=28$ o,374 diperoleh 20 butir soal yang valid, Setelah itu baru dibandingkan dengan harga korelasi yakni $\mathrm{r}_{\text {hitung}}$. Hasil post-test dari butir soal 1 mendapatkan nilai $\mathrm{r}_{\text {hitung }}=0,4223$ dan $\mathrm{r}_{\text {tabel }}=$ o,374 kesimpulanya $\mathrm{r}_{\text {hitung }}>\mathrm{r}_{\text {tabel }}$ maka butir soal 1 dinyatakan valid

\begin{tabular}{|c|c|c|c|c|c|c|}
\hline \multirow{2}{*}{$\begin{array}{l}\text { But } \\
\mathrm{ir} / \mathrm{i} \\
\text { te } \\
\mathrm{m}\end{array}$} & \multicolumn{3}{|c|}{ Pre-test } & \multicolumn{3}{|c|}{ Post-test } \\
\hline & $\begin{array}{c}\mathrm{r}_{\text {hitun }} \\
g\end{array}$ & $\begin{array}{l}\mathrm{r}_{t a} \\
b e l\end{array}$ & $\begin{array}{c}\text { Valid } \\
\text { /inval } \\
\text { id }\end{array}$ & $\begin{array}{c}\mathrm{r}_{\text {hitu }} \\
n g\end{array}$ & $\begin{array}{l}\mathrm{r}_{t a} \\
b e l\end{array}$ & $\begin{array}{c}\text { Valid } \\
\text { /inval } \\
\text { id }\end{array}$ \\
\hline 1 & $\begin{array}{c}- \\
0,0 \\
496\end{array}$ & $\begin{array}{c}\text { o, } \\
37 \\
4\end{array}$ & $\begin{array}{c}\text { Invali } \\
\mathrm{d}\end{array}$ & $\begin{array}{c}0,4 \\
22 \\
29\end{array}$ & $\begin{array}{r}\text {, } \\
37 \\
4\end{array}$ & Valid \\
\hline 2 & $\begin{array}{c}0,42 \\
533\end{array}$ & $\begin{array}{c} \\
37 \\
4 \\
\end{array}$ & valid & $\begin{array}{c}0,0 \\
193 \\
5 \\
\end{array}$ & $\begin{array}{r}T \\
0, \\
37 \\
4 \\
\end{array}$ & $\begin{array}{c}\text { Invali } \\
\mathrm{d}\end{array}$ \\
\hline 3 & $\begin{array}{l}0,47 \\
345\end{array}$ & $\begin{array}{c}\text { o, } \\
37 \\
4\end{array}$ & valid & $\begin{array}{c}0,4 \\
617 \\
4\end{array}$ & $\begin{array}{r}\text { O, } \\
37 \\
4\end{array}$ & Valid \\
\hline 4 & $\begin{array}{c}0,45 \\
791\end{array}$ & $\begin{array}{c} \\
37 \\
4 \\
\end{array}$ & valid & $\begin{array}{c}0,5 \\
99 \\
94 \\
\end{array}$ & $\begin{array}{r}1 \\
37 \\
4 \\
\end{array}$ & Valid \\
\hline 5 & $\begin{array}{l}0,51 \\
297\end{array}$ & $\begin{array}{c}0 \\
37 \\
4 \\
\end{array}$ & valid & $\begin{array}{c}0,5 \\
210 \\
9\end{array}$ & $\begin{array}{r}0, \\
37 \\
4\end{array}$ & Valid \\
\hline 6 & $\begin{array}{c}- \\
0,34 \\
46 \\
\end{array}$ & $\begin{array}{c}\text { o, } \\
37 \\
4 \\
\end{array}$ & $\begin{array}{c}\text { Invali } \\
\mathrm{d}\end{array}$ & $\begin{array}{c}- \\
0,3 \\
672 \\
\end{array}$ & $\begin{array}{r}0, \\
37 \\
4 \\
\end{array}$ & $\begin{array}{c}\text { Invali } \\
\mathrm{d}\end{array}$ \\
\hline 7 & $\begin{array}{l}0,41 \\
863\end{array}$ & $\begin{array}{c} \\
37 \\
4\end{array}$ & valid & $\begin{array}{c}0,4 \\
441 \\
4\end{array}$ & $\begin{array}{r}0, \\
37 \\
4\end{array}$ & Valid \\
\hline 8 & $\begin{array}{c}- \\
0,10 \\
03 \\
\end{array}$ & $\begin{array}{c}0, \\
37 \\
4 \\
\end{array}$ & $\begin{array}{c}\text { Invali } \\
\mathrm{d}\end{array}$ & $\begin{array}{c}0,4 \\
04 \\
68 \\
\end{array}$ & $\begin{array}{r}\text {, } \\
37 \\
4 \\
\end{array}$ & Valid \\
\hline 9 & $\begin{array}{c}0,46 \\
868\end{array}$ & $\begin{array}{c}\text { o, } \\
37 \\
4 \\
\end{array}$ & valid & $\begin{array}{c}0,4 \\
07 \\
58 \\
\end{array}$ & $\begin{array}{r}0, \\
37 \\
4\end{array}$ & Valid \\
\hline 10 & $\begin{array}{c}0,44 \\
095\end{array}$ & $\begin{array}{c}\text { o, } \\
37 \\
4\end{array}$ & valid & $\begin{array}{c}0,4 \\
63 \\
69\end{array}$ & $\begin{array}{r}0, \\
37 \\
4\end{array}$ & Valid \\
\hline 11 & $\begin{array}{c}- \\
0,0 \\
223 \\
\end{array}$ & $\begin{array}{c}\text { o, } \\
37 \\
4 \\
\end{array}$ & $\begin{array}{c}\text { Invali } \\
\mathrm{d}\end{array}$ & $\begin{array}{c}0,0 \\
774 \\
1\end{array}$ & $\begin{array}{r}1 \\
0, \\
37 \\
4 \\
\end{array}$ & $\begin{array}{c}\text { Invali } \\
\mathrm{d}\end{array}$ \\
\hline 12 & $\begin{array}{l}0,47 \\
345\end{array}$ & $\begin{array}{c}\text { o, } \\
37 \\
4 \\
\end{array}$ & valid & $\begin{array}{c}0,6 \\
\text { oo } \\
57 \\
\end{array}$ & $\begin{array}{r}0, \\
37 \\
4 \\
\end{array}$ & Valid \\
\hline 13 & $\begin{array}{l}0,61 \\
004\end{array}$ & $\begin{array}{c}\text { o, } \\
37 \\
4 \\
\end{array}$ & valid & $\begin{array}{c}0,5 \\
02 \\
8 \\
\end{array}$ & $\begin{array}{r}\text { o, } \\
37 \\
4 \\
\end{array}$ & Valid \\
\hline 14 & $\begin{array}{c}- \\
0,57 \\
58\end{array}$ & $\begin{array}{c}0 \\
37 \\
4\end{array}$ & $\begin{array}{c}\text { Invali } \\
\mathrm{d}\end{array}$ & $\begin{array}{c}- \\
0,2 \\
38 \\
7\end{array}$ & $\begin{array}{c}\text { o, } \\
37 \\
4\end{array}$ & $\begin{array}{c}\text { Invali } \\
\mathrm{d}\end{array}$ \\
\hline 15 & $\begin{array}{c}0,42 \\
06\end{array}$ & $\begin{array}{c}\text { o, } \\
37 \\
4\end{array}$ & valid & $\begin{array}{c}0,4 \\
29 \\
62\end{array}$ & $\begin{array}{r}0, \\
37 \\
4\end{array}$ & Valid \\
\hline 16 & - & 0 & Invali & - & $\mathrm{O}$, & Invali \\
\hline
\end{tabular}




\begin{tabular}{|c|c|c|c|c|c|c|}
\hline & $\begin{array}{c}0,56 \\
23\end{array}$ & $\begin{array}{c}37 \\
4\end{array}$ & $\mathrm{~d}$ & $\begin{array}{c}0,1 \\
07 \\
6 \\
\end{array}$ & $\begin{array}{c}37 \\
4\end{array}$ & $\mathrm{~d}$ \\
\hline 17 & $\begin{array}{c}0,54 \\
562\end{array}$ & $\begin{array}{c} \\
37 \\
4 \\
\end{array}$ & valid & $\begin{array}{c}0,4 \\
451 \\
1\end{array}$ & $\begin{array}{c}\text {, } \\
37 \\
4 \\
\end{array}$ & Valid \\
\hline 18 & $\begin{array}{c}0,49 \\
224\end{array}$ & $\begin{array}{c}0, \\
37 \\
4 \\
\end{array}$ & valid & $\begin{array}{c}0,4 \\
274\end{array}$ & $\begin{array}{c}0, \\
37 \\
4 \\
\end{array}$ & Valid \\
\hline 19 & $\begin{array}{l}0,55 \\
289\end{array}$ & $\begin{array}{c}0, \\
37 \\
4 \\
\end{array}$ & valid & $\begin{array}{c}0,3 \\
97 \\
03 \\
\end{array}$ & $\begin{array}{c}0, \\
37 \\
4 \\
\end{array}$ & Valid \\
\hline 20 & $\begin{array}{c}0,44 \\
939\end{array}$ & $\begin{array}{c}0, \\
37 \\
4 \\
\end{array}$ & valid & $\begin{array}{c}0,4 \\
10 \\
03 \\
\end{array}$ & $\begin{array}{c}0, \\
37 \\
4 \\
\end{array}$ & Valid \\
\hline 21 & $\begin{array}{c}0,42 \\
156\end{array}$ & $\begin{array}{c}\text { o, } \\
37 \\
4\end{array}$ & Valid & $\begin{array}{c}0,4 \\
472 \\
1\end{array}$ & $\begin{array}{c}0, \\
37 \\
4\end{array}$ & Valid \\
\hline 22 & $\begin{array}{c}- \\
0,15 \\
23 \\
\end{array}$ & $\begin{array}{c}0, \\
37 \\
4 \\
\end{array}$ & $\begin{array}{c}\text { Invali } \\
\mathrm{d}\end{array}$ & $\begin{array}{c}- \\
0,1 \\
53\end{array}$ & $\begin{array}{c}\text { o, } \\
37 \\
4 \\
\end{array}$ & $\begin{array}{c}\text { Invali } \\
\mathrm{d}\end{array}$ \\
\hline 23 & $\begin{array}{l}0,51 \\
648\end{array}$ & $\begin{array}{c}0, \\
37 \\
4 \\
\end{array}$ & valid & $\begin{array}{c}0,4 \\
125 \\
5 \\
\end{array}$ & $\begin{array}{c}0, \\
37 \\
4 \\
\end{array}$ & Valid \\
\hline 24 & $\begin{array}{l}0,44 \\
939\end{array}$ & $\begin{array}{c}\text { o, } \\
37 \\
4 \\
\end{array}$ & valid & $\begin{array}{c}0,4 \\
22 \\
29 \\
\end{array}$ & $\begin{array}{c}\mathrm{O}, \\
37 \\
4 \\
\end{array}$ & Valid \\
\hline 25 & $\begin{array}{c}- \\
0,33 \\
24\end{array}$ & $\begin{array}{c}0, \\
37 \\
4\end{array}$ & $\begin{array}{c}\text { Invali } \\
\mathrm{d}\end{array}$ & $\begin{array}{c}- \\
0,1 \\
93 \\
5\end{array}$ & $\begin{array}{c}\mathrm{O}, \\
37 \\
4\end{array}$ & $\begin{array}{c}\text { Invali } \\
\text { d }\end{array}$ \\
\hline 26 & $\begin{array}{l}0,41 \\
244\end{array}$ & $\begin{array}{c}0, \\
37 \\
4\end{array}$ & valid & $\begin{array}{c}- \\
0,3 \\
07 \\
3 \\
\end{array}$ & $\begin{array}{c}0, \\
37 \\
4\end{array}$ & $\begin{array}{c}\text { Invali } \\
\text { d }\end{array}$ \\
\hline 27 & $\begin{array}{c}- \\
0,46 \\
49\end{array}$ & $\begin{array}{c}0, \\
37 \\
4\end{array}$ & $\begin{array}{c}\text { Invali } \\
\mathrm{d}\end{array}$ & $\begin{array}{c}- \\
0,0 \\
80 \\
4\end{array}$ & $\begin{array}{c}\text { o, } \\
37 \\
4\end{array}$ & $\begin{array}{c}\text { Invali } \\
\mathrm{d}\end{array}$ \\
\hline 28 & $\begin{array}{l}0,39 \\
068\end{array}$ & $\begin{array}{c}0 \\
37 \\
4 \\
\end{array}$ & valid & $\begin{array}{c}0,4 \\
02 \\
24 \\
\end{array}$ & $\begin{array}{c}0, \\
37 \\
4 \\
\end{array}$ & Valid \\
\hline 29 & $\begin{array}{c}- \\
0,46 \\
45 \\
\end{array}$ & $\begin{array}{c}0 \\
37 \\
4 \\
\end{array}$ & $\begin{array}{c}\text { Invali } \\
\mathrm{d}\end{array}$ & $\begin{array}{c}0,0 \\
113 \\
2 \\
\end{array}$ & $\begin{array}{c}, \\
37 \\
4 \\
\end{array}$ & $\begin{array}{c}\text { Invali } \\
\text { d }\end{array}$ \\
\hline 30 & $\begin{array}{c}0,46 \\
455\end{array}$ & $\begin{array}{c}0, \\
37 \\
4 \\
\end{array}$ & valid & $\begin{array}{c}0,5 \\
59 \\
97 \\
\end{array}$ & $\begin{array}{c}\text { o, } \\
37 \\
4 \\
\end{array}$ & Valid \\
\hline
\end{tabular}

\section{e. Pengujian Reliabilitas}

Uji reliabilitas berupa tes digunakan Kuder Richardson 20 (KR-20).

Adapun rumus KR-20 sebagai berikut:

$\mathbf{r}_{11}=\left(\frac{n}{n-1}\right)\left(\frac{s^{2}-\Sigma p q}{s^{2}}\right)$

Dimana:

$\mathrm{R}_{11}=$ reliabilitas tes secara keseluruhan

$\mathrm{p}=$ proporsi subjek yang menjawab item dengan benar

$\mathrm{q}=$ proporsi subjek yang menjawab item dengan salah ( $\mathrm{q}$ $=1-\mathrm{p})$

$\sum \mathrm{pq}=$ jumlah hasil perkalian antara $\mathrm{p}$ dan $\mathrm{q}$

$\mathrm{n} \quad=$ banyaknya item

$S^{2}=$ standar deviasi dari tes (standar

deviasi adalah akar varians)

Dari hasil perhitungan uji reliabilitas pre-test membandingkan $\mathrm{r}_{\text {hitung }}=0.375$ dengan $\mathrm{r}_{\text {tabel }}=0,374$ dengan demikian maka soal instrumen dapat disimpulkan reliabel, karena lebih besar dari r product moment $(0,375>0,374)$, maka dapat disimpulkan instrument penelitian tersebut reliabel. Berdasarkan kriteria reliabilitas instrument soal tersebut memiliki reliabilitas rendah. Dan hasil perhitungang uji reliabilitas post-test membandingkan $\mathrm{r}_{\text {hitung }}=0,740$ dengan $\mathrm{r}_{\text {tabel }}=0,374$ dengan demikian maka soal instrumen dapat disimpulkan reliabel, karena lebih besar dari $\mathrm{r}$ product moment $(0,740>0,374)$, maka dapat disimpulkan instrument penelitian tersebut reliabel. Berdasarkan kriteria reliabilitas instrument, soal tersebut memiliki reliabilitas tinggi.

\section{Jenis Dan Sumber Data - Jenis Data}

Menurut Cholid Narbuko, (2003:66), umumnya data terbagi atas data kualitatif dan kuantitatif. Data kualitatif adalah jenis data yang berbentuk kata-kata, kalimat, atau pendapat dari respon dan atau informan penelitian. Sedangkan data kuantitatif adalah data yang berbentuk angka, atau data kualitatif yang diangkakan (scoring). Namun demikian, data dalam penelitian ini selalu dihubungkan dengan skala pengukuran.

\section{- Sumber Data}

Sumber data dalam penelitian ini dapat dibedakan menjadi dua macam yaitu sumber data primer dan sumber data sekunder.

Adapun data yang digunakan dalam penelitian ini adalah sumber data primer dan data sekunder. Untuk dokumentasi peneliti berdasar pada data sekunder dan untuk tes peneliti berdasar pada data primer.

\section{Identifikasi Dan Definisi Operasional Variabel}

\section{- Identifikasi Variabel}

Variabel penelitian adalah suatu atribut atau sifat atau nilai dari orang, obyek atau kegiatan yang mempunyai variasi tertentu yang ditetapkan oleh peneliti untuk dipelajari dan kemudian ditarik kesimpulanya.

Dalam penelitian terdapat dua (2) variabel penelitian yaitu:

\section{a. Variabel bebas (independen)}

Variabel bebas (independen) sering disebut sebagai variabel stimulus, prediktor, antecedent. Dalam bahasa indonesia sering disebut sebagai variabel bebas. Variabel bebas merupakan variabel yang mempengaruhi atau yang menjadi sebab perubahannya atau timbulnya variabel dependen (terikat) (Sugiyono, 2014: 39).

Dalam penelitian ini terdapat dua variabel bebas yaitu model pembelajaran inkuiri tetbimbing $(X 1)$ dan model pembelajaran Inkuiri training $(X 2)$.

b. Variabel terikat (dependen)

Variabel terikat (dependen) dalam penelitian ini adalah hasil belajar (Y) PKn siswa kelas XI SMAN 2 Woha. Dalam hal ini adalah hasil belajar siswa pada tingkat penguasaan materi dalam mata pelajaran PKn berdasarkan indikator pencapaian hasil belajar dengan instrumen nilai tes dan hasil dokumentasi dengan skala pengukurannya adalah interval.

\section{Definisi Operasional Variabel \\ - Inkuiri Terbimbing}

Inkuiri terbimbing merupakan model pembelajaran dimana dalam proses kegiatan belajar dan mengajar guru membimbing dan mengarahkan siswa dengan mengajukan permasalahan, dan kemudian guru bersama siswa mencari pemecahan masalah yang telah diajukan oleh guru kepada siswa dengan mengadakan penelitian secara mandiri siswa akan menemukan konsep-konsep dari permasalahan dalam pembelajarannya, kemudian akan menyimpulkan hasil penelitian serta pengamatannya dan akan di sampaikan oleh setiap siswa kepada siswa lainnya. 


\section{- Inkuiri Training}

Model pembelajaran inkuiri training merupakan pembelajaran yang melibatkan siswa dalam masalah yang sebenarnya dalam penelitian dengan menghadapkan anak didik pada bidang penelitian, membantu siswa mengidentifikasi masalah yang konseptual atau metodologis dalam bidang penelitian dan mengajak siswa untuk merancang cara dalam mengatasi masalah. Pada waktu yang sama siswa akan menemukan dan mencapai aspek yang baik dalam pengetahuan dan dapat dipertanggungjawabkan.

\section{- Hasil Belajar PKn}

Hasil belajar adalah tingkatan penguasaan yang dimiliki siswa setelah melalui serangkaian kegiatan yang telah dilakukan dengan menerapkan model pembelajaran Inkuiri terbimbing dan model pembelajaran inkuiri training yang ditunjukkan dalam berbagai bentuk seperti perubahan pengetahuan, pemahaman, sikap dan tingkah laku, keterampilan, kecakapan, kebiasaan serta aspek-aspek lain yang ada dalam diri individu yang belajar.

\section{Metode Analisis Data}

Dalam penelitian kuantitatif, teknik analisis data yang digunakan sudah jelas, yaitu diarahkan untuk menjawab rumusan masalah atau menguji hipotesis yang telah dirumuskan dalam proposal.

\section{- Uji Prasyarat Analisis}

Dalam penelitian ini untuk menganalisa data digunakan rumus Chi Kuadrat untuk menguji normalitas data dan uji variansi untuk menguji homogenitas data.

\section{- Uji Normalitas}

Uji normalitas bertujuan untuk mengetahui apakah sampel yang diambil berasal dari populasi yang berdistribusi normal atau tidak. uji normalitas dalam penelitian ini menggunakan uji Chi-Kuadrat. Adapun rumus uji chi-kuadrad adalah :

$$
X^{2}=\sum \frac{(f o-f e)^{2}}{f e}
$$

Keterangang :

$f_{o}=$ frekuensi $/$ jumlah data observasi

$f_{e}=$ frekuensi harapan

Dengan $\mathrm{Db}=\mathrm{n}-1$ dan taraf signifikan $\alpha=0.05$. jika $X_{\text {hitung }}^{2}<X_{\text {tabel }}$, maka data berdistribusi normal $(X=\mu)$ dan jika $X_{\text {hitung }}^{2} \geq X_{\text {tabel }}^{2}$, maka data tidak berdistribusi normal $(X \neq \mu)$.

\section{- Uji Homogenitas}

Dalam analisis variansi yang menguji kesamaan beberapa rata-rata, diasumsikan populasinya mempunyai variansi yang homogen. Maka statistik F dapat dihitung dengan rumus :

\section{$F_{\text {hitung }}=\frac{\text { variansterbesar }}{\text { variansterkecil }}$}

Yang memiliki distribusi Snedecor F dengan derajat kebebasan $\left(n_{1}-1, n_{2}-1\right)$ dengan asumsi hipotesis nol benar. Derajat kebebasan $n_{1}-1$ disebut derajat kebebasan pembilang, dan derajat kebebasan $n_{2}-1$ disebut derajat kebebasan penyebut. Yang berdasar pada kriteria pengambilan keputusan : (Astuti, $2014: 69$ )
Jika $F_{\text {hitung }}<F_{\text {tabel }}$, maka data homogen Jika $F_{\text {hitung }} \geq F_{\text {tabel }}$, maka data tidak homogen

\section{- Uji Hipotesis}

Untuk menguji hipotesi perbedaan pengaruh antara model pembelajaran inkuiri terbimbing dan model pembelajaran inkuiri training terhadap pencapaian hasil belajar PKn siswa kelas XI SMAN 2 Woha dilakukan dengan uji t-test dengan rumus adalah sebagai berikut :

\section{Rumus t-tes Polled Varians

$$
\mathrm{t}=\frac{x 1-x 2}{\sqrt{\frac{(n 1-1) S_{1}^{2}+(n 1-1) S z^{2}}{n 1+n n-2}\left\{\frac{1}{n 1}+\frac{1}{n 2}\right\}}}
$$

keterangan:

$\mathrm{t}=$ Nilai $\mathrm{t}$ yang dihitung

$\mathrm{x}=$ Nilai rata-rata kelas eksperimen

$\mathrm{x}_{2}=$ Nilai rata-rata kelas kontrol

$\mathrm{S}_{1}{ }^{2}=$ Varians kelas eksperimen

$\mathrm{S}_{1}{ }^{2}=$ Varians kelas control

$\mathrm{n}_{1}=$ Jumlas siswa kelas eksperimen

$\mathrm{n}_{2}=$ Jumlah siswa kelas kontrol

Dengan ketentuan jika $t_{\text {hitung }}>t_{\text {tabel }}$ maka hipotesis alternatif diterima dan Hipotesis nol ditolak jika $t_{\text {hitumg }}<$ $t_{\text {tabel }}$ maka hipotesis nol (Ho) diterima dan Hipotesis alternatif ditolak. (Sugiyono, $2011: 196)$.

\section{HASIL DAN PEMBAHASAN}

Penelitian ini merupakan penelitian Quasi Experimental Desaign melalui non rendomize pretesposttest control group Design. Penelitian eksperimen ini telah dilaksanakan pada tanggal o1 Juli sampai 31 Juli 2016 di SMAN 2 Woha pada kelas XI IPA 2 sebagai kelas eksperimen yang berjumlah 25 orang dan XI IPA 3 sebagai kelas kontrol yang berjumlah 28 orang. Untuk melakukan uji coba instrumen penelitian ini.

\section{- Deskripsi Data Hasil Penelitian}

Untuk mendiskripsikan hasil penelitian ini, langkah pertama yang dilakukan adalah pengukuran hasil belajar awal (pre-test) peserta didik dengan menggunakan model pembelajaran inkuiri terbimbing dan model pembelajaran inkuiri training kemudian dikenakan perlakuan untuk jangka waktu tertentu dengan menggunakan model pembelajaran inkuiri terbimbing dengan inkuiri training untuk mendapatkan hasil belajar akhir (post-test) siswa.

\section{- Deskripsi Data Hasil Belajar Siswa Kelompok Kontrol}

Sebaran frekuensi skor nilai hasil belajar PKn pada siswa kelas kontrol dengan menggunakan model pembelajaran inkuiri training. Data yang dikumpulkan melalui hasil belajar siswa pada kelompok kontrol dengan menggunakan model pembelajaran inkuiri training dengan jumlah siswa 28 , dimana nilai rata-rata kelas kontrol dengan nilai tertinggi 85 dan nilai terendah 50.

Adapun data mengenai hasil belajar siswa yang menggunakan model pembelajaran inkuiri training dapat dilihat pada tabel berikut:

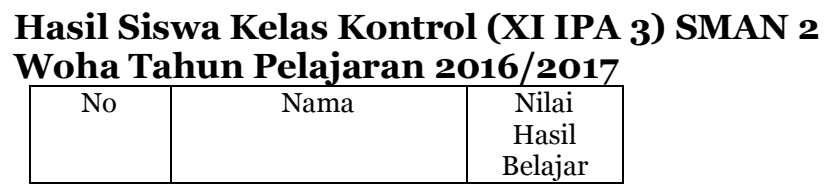




\begin{tabular}{|c|c|c|}
\hline 1 & Afjalul Rahman & 50 \\
\hline 2 & Anti Kurniati & 65 \\
\hline 3 & Arif Sanjaya & 75 \\
\hline 4 & Asmaul Husnah & 60 \\
\hline 5 & Ayu Putri Ningsih & 75 \\
\hline 6 & Eka Susilawati & 55 \\
\hline 7 & Fiqriah & 70 \\
\hline 8 & Fitri Yanti & 65 \\
\hline 9 & Jainul Arifin & 80 \\
\hline 10 & Jerni & 85 \\
\hline 11 & Julyana & 75 \\
\hline 12 & Kurniawati & 75 \\
\hline 13 & Mardiana & 60 \\
\hline 14 & Megawati & 60 \\
\hline 15 & Nadia & 55 \\
\hline 16 & Nur Khairunnisa & 70 \\
\hline 17 & Puput Kurnia & 85 \\
\hline 18 & Rahmawati & 55 \\
\hline 19 & Ratih Kusmawati & 75 \\
\hline 20 & Sahru Ramadhan & 60 \\
\hline 21 & Sri Andi Mulyana & 70 \\
\hline 22 & Sri Aryani Wati & 65 \\
\hline 23 & $\begin{array}{l}\text { Sri Wahyuningsih } \\
\text { B. }\end{array}$ & 80 \\
\hline 24 & Sri Yani & 50 \\
\hline 25 & Suryadin & 80 \\
\hline 26 & Syanti Sulastri & 65 \\
\hline 27 & Wajirah Amalia & 75 \\
\hline 28 & Yuni Ansari & 75 \\
\hline \multicolumn{2}{|r|}{ Jumlah } & 1910 \\
\hline
\end{tabular}

Membuat Tabel Distribusi Frekuensi Hasil Belajar Kelas Kontrol. Berikut ini adalah nilai hasi belajar siswa pada mata pelajaran PKn dengan menggnakan model Pembelajaran inkuiri training Kelas XI IPA 3 di SMA Negeri 2 Woha dengan jumlah sampel 28 siswa :

\begin{tabular}{|l|l|l|l|l|l|l|l|l|l|}
\hline 5 & 5 & 5 & 5 & 5 & 6 & 6 & 6 & 6 & 6 \\
0 & 0 & 5 & 5 & 5 & 0 & 0 & 0 & 0 & 5 \\
\hline 6 & 6 & 6 & 7 & 7 & 7 & 7 & 7 & 7 & 7 \\
5 & 5 & 5 & 0 & 0 & 0 & 5 & 5 & 5 & 5 \\
\hline 7 & 7 & 7 & 8 & 8 & 8 & 8 & 8 & & \\
5 & 5 & 5 & 0 & 0 & 0 & 5 & 5 & & \\
\hline
\end{tabular}

$$
\mathrm{H}=85
$$$$
\mathrm{L}=50
$$

Ditentukan dengan rumus Sturges

$$
K=1+3 \cdot 3 \log n
$$

Dimana :

$\mathrm{K}=$ jumlah kelas interval

$\mathrm{n}=$ jumlah data observasi

$\log =\operatorname{logaritma}$

Sugiyono (2015:35)

$\mathrm{K}=1+3 \cdot 3 \log 28=1+3 \cdot 3(1,447)=5,7751$ (dibulatkan menjadi 6)

Jadi, jumlah kelas interval 6

$\mathrm{R}=(\mathrm{H}-\mathrm{L})+1=(85-50)+1=36$

$\mathrm{i}=\frac{R}{K}=\frac{36}{6}=6$

Mean (rata-rata)

$\mathrm{M}=\frac{1910}{28}=68.21$

Skor Hasil Belajar Siswa Pada Kelas Kontrol yang Menggunakan Model Pembelajaran Inkuiri Training

\begin{tabular}{|c|c|c|c|c|c|c|c|}
\hline No & $\begin{array}{c}\text { Inte } \\
\text { rval }\end{array}$ & F & $\begin{array}{c}\text { X } \\
\text { i }\end{array}$ & fi.xi & xi-x & $\begin{array}{c}(x i- \\
\text { x) } 2\end{array}$ & $\begin{array}{c}\text { fi(xi- } \\
\text { x) } 2\end{array}$ \\
\hline 1 & 50 & 5 & 5 & 265 & - & 231, & 1156,7 \\
& -55 & & 3 & & 15,2 & 34 & \\
\hline
\end{tabular}

\begin{tabular}{|c|c|c|c|c|c|c|c|}
\hline & & & & & 1 & & \\
\hline 2 & $56-$ & 4 & 5 & 236 & - & 84, & 339,28 \\
& 61 & & 9 & & 9,21 & 82 & \\
\hline 3 & 62 & 4 & 6 & 260 & - & 10,3 & 41,2 \\
& -67 & & 5 & & 3,21 & 0 & \\
\hline 4 & 68 & 3 & 7 & 213 & 2,79 & 7,78 & 23,34 \\
& -73 & & 1 & & & & \\
\hline 5 & $74-$ & 7 & 7 & 539 & 8,79 & 77,2 & 540,82 \\
& 79 & & 7 & & & 6 & \\
\hline 6 & 80 & 5 & 8 & 415 & 14,7 & 218, & 1093,7 \\
& - & & 3 & & 9 & 74 & \\
& 85 & & & & & & \\
\hline \multicolumn{2}{|r|}{ Jumlah } & 28 & & 192 & & 630 & 3195,0 \\
& & & 8 & &, 24 & 4 \\
\hline
\end{tabular}

Keterangan :

$\mathrm{F} \quad=$ jumlah data observasi

$\mathrm{Xi}=$ nilai tengah kelas interval

Fi.xi = jumlah data observasi dikali dengan nilai tengah kelas interval

$\mathrm{xi}-\mathrm{x} \quad=$ nilai rata-rata siswa

$\mathrm{SD}=\sqrt{\frac{\sum f i(x i-x)^{3}}{n-1}}=\sqrt{\frac{3195,04}{27}}=\sqrt{118,33}=10,87$

Berdasarkan hasil perhitungan nilai Mean dari data kelas kontrol adalah sebesar 68,21 sedang SD 10,87. untuk mengetahui nilai tertinggi yang dikategorikan sangat baik adalah dengan menjumlahkan nilai mean dan standar deviasi $68,21+3.0+10,87=82,08$. Hal ini berarti nilai perolehan siswa yang dikatakan sangat baik apabila memperoleh nilai diatas 82.08. Sedangkan untuk mengetahui nilai perolehan siswa yang dikategorikan baik $68.21+1.5+10.87=80.58$. Perolehan nilai yang dikatakan sedang $68.21+0.5+$ $10.87=79.58$. Perolehan nilai yang dikategorikan kurang $68.21-0.5-10.87=56.63$. sedangkan perolehan nilai yang dikategorikan sangat kurang adalah $68.21-1.5-10.87=55.84$. hal ini berarti nilai perolehan siswa yang dikatakan sangat kurang apabila memperoleh nilai kurang dari 55.84.

Data Rincian Klasifikasi Hasil Belajar PPKn

\begin{tabular}{|c|c|c|c|}
\hline No. & Nilai & $\begin{array}{c}\text { Kriteria } \\
\text { Penilaian }\end{array}$ & $\begin{array}{c}\text { Jumlah } \\
\text { Siswa }\end{array}$ \\
\hline 1. & $\geq 82,08$ & Sangat Baik & 2 \\
\hline 2. & $\geq 80,58$ & Baik & 3 \\
\hline 3. & $\geq 79,58$ & Cukup & 18 \\
\hline 4. & $\leq 56,63$ & Kurang & 5 \\
\hline 5 . & $\leq 55,84$ & $\begin{array}{l}\text { Sangat } \\
\text { Kurang }\end{array}$ & $\mathrm{O}$ \\
\hline \multicolumn{3}{|c|}{ Jumlah } & 28 \\
\hline
\end{tabular}
Kelas Eksperimen

Berdasarkan data diatas diketahui jumlah siswa yang memperoleh hasil belajar sangat baik berjumlah 2 orang, Baik berjumlah 3, cukup berjumlah 18, kurang berjumlah 5 , sangat kurang berjumlah 0 .

\section{Deskripsi Data Hasil Belajar Siswa Kelompok Eksperimen}

Sebaran frekuensi skor nilai hasil belajar PKn pada siswa kelas kontrol dengan menggunakan model pembelajaran inkuiri terbimbing. Data yang dikumpulkan melalui hasil belajar siswa pada kelompok eksperimen dengan menggunakan model pembelajaran inkuiri terbimbing dengan jumlah siswa 25, dimana nilai rata-rata kelas kontrol dengan nilai tertinggi 95 dan nilai terendah 60. 
Adapun data mengenai hasil belajar siswa yang menggunakan model pembelajaran inkuiri terbimbing dapat dilihat pada tabel berikut:

\section{Hasil Siswa Kelas Eksperimen (XI IPA 2) SMAN}

2 Woha Tahun Pelajaran 2016/2017

\begin{tabular}{|c|c|c|}
\hline No & Nama & $\begin{array}{c}\text { Nilai Hasil } \\
\text { Belajar }\end{array}$ \\
\hline 1 & Ahmad Muntasar & 60 \\
\hline 2 & Albar & 85 \\
\hline 3 & Akbar & 65 \\
\hline 4 & Amirul Mu'min & 80 \\
\hline 5 & Aprilianingsih & 65 \\
\hline 6 & Astagina & 85 \\
\hline 7 & Dela Delia Feronika & 90 \\
\hline 8 & Dian Andriani & 95 \\
\hline 9 & Irwanto & 70 \\
\hline 10 & Heni Handriani & 85 \\
\hline 11 & Ira Setiawati Fitria & 85 \\
\hline 12 & Kamaluddin & 75 \\
\hline 13 & Khairul Bahri & 75 \\
\hline 14 & M. Rizky & 80 \\
\hline 15 & Mega Selviyana & 70 \\
\hline 16 & Miftahul Jannah & 65 \\
\hline 17 & Muhammad Salki & 90 \\
\hline 18 & Nining Wahyuningsih & 75 \\
\hline 19 & Nurfikhiyah Auliya & 80 \\
\hline 20 & Nurhidayat & 70 \\
\hline 21 & Nuryuli Alanuri & 75 \\
\hline 22 & Rizki Ziran Putri & 70 \\
\hline 23 & Rohana & 80 \\
\hline 24 & Rukayah & 85 \\
\hline 25 & Salmah Fajrianti & 65 \\
\hline \multicolumn{2}{|c|}{ Jumlah } & 1920 \\
\hline
\end{tabular}

Membuat Tabel Distribusi Frekuensi Hasil Belajar Kelas Kontrol. Berikut ini adalah nilai hasi belajar siswa pada mata pelajaran PKn dengan menggunakan model Pembelajaran inkuiri terbimbing Kelas XI IPA 2 di SMA Negeri 2 Woha dengan jumlah sampel 25 siswa :

\begin{tabular}{|l|l|l|l|l|l|l|l|l|l|}
\hline 60 & 65 & 65 & 65 & 65 & 70 & 70 & 70 & 70 & 75 \\
\hline 75 & 75 & 75 & 80 & 80 & 80 & 80 & 85 & 85 & 85 \\
\hline 85 & 85 & 90 & 90 & 95 & & & & & \\
\hline \multicolumn{10}{l}{$=95$} \\
$\mathrm{~L}=60$
\end{tabular}

Ditentukan dengan rumus Sturges

Dimana :

$$
K=1+3 \cdot 3 \log n
$$

$\mathrm{K}=$ jumlah kelas interval

$\mathrm{n}=$ jumlah data observasi

$\log =\operatorname{logaritma}$

Sugiyono (2015:35)

$\mathrm{K}=1+3 \cdot 3 \log 25=1+3 \cdot 3(1,397)=6$ (dibulatkan menjadi 6)

Jadi, jumlah kelas interval 6

$$
\begin{aligned}
& \mathrm{R}=(\mathrm{H}-\mathrm{L})+1=(85-50)+1=36 \\
& \mathrm{i}=\frac{R}{K}=\frac{36}{6}=6 \\
& \text { Mean (rata-rata) } \\
& \mathrm{M}=\frac{1920}{25}=76,8
\end{aligned}
$$

\begin{tabular}{|c|c|c|c|c|c|c|c|}
\hline & 83 & & & 4 & & 4 & 6 \\
\hline 5 & $\begin{array}{c}84- \\
89\end{array}$ & 5 & 87 & $\begin{array}{c}43 \\
5\end{array}$ & 10,2 & $\begin{array}{c}104 \\
04\end{array}$ & $\begin{array}{c}520 \\
2\end{array}$ \\
\hline 6 & $\begin{array}{c}90- \\
95\end{array}$ & 3 & 93 & $\begin{array}{c}27 \\
9 \\
\end{array}$ & 16,2 & $\begin{array}{c}262 \\
44 \\
\end{array}$ & $\begin{array}{c}787 \\
32 \\
\end{array}$ \\
\hline \multicolumn{2}{|c|}{ Jumlah } & & & $\begin{array}{l}19 \\
29 \\
\end{array}$ & 7,2 & $\begin{array}{c}638, \\
64 \\
\end{array}$ & $\begin{array}{r}258 \\
6,6 \\
\end{array}$ \\
\hline
\end{tabular}

Skor Hasil Belajar Siswa Pada Kelas eksperimen yang Menggunakan Model Pembelajaran Inkuiri Terbimbing

\begin{tabular}{|c|c|c|c|c|c|c|c|}
\hline $\begin{array}{c}\mathrm{N} \\
\mathrm{o}\end{array}$ & $\begin{array}{c}\text { Inter } \\
\text { val }\end{array}$ & $\mathrm{F}$ & $\mathrm{xi}$ & $\begin{array}{c}\text { fi.x } \\
\mathrm{i}\end{array}$ & $\mathrm{xi}-\mathrm{x}$ & $\begin{array}{c}(\mathrm{xi}- \\
\mathrm{x})^{2}\end{array}$ & $\begin{array}{c}\mathrm{fi}(\mathrm{xi} \\
-\mathrm{x})^{2}\end{array}$ \\
\hline 1 & $\begin{array}{c}60- \\
65\end{array}$ & 5 & 63 & $\begin{array}{c}31 \\
5\end{array}$ & $\begin{array}{c}- \\
13,8\end{array}$ & $\begin{array}{c}190, \\
44\end{array}$ & $\begin{array}{c}952, \\
2\end{array}$ \\
\hline 2 & $\begin{array}{c}66- \\
71\end{array}$ & 4 & 69 & $\begin{array}{c}27 \\
6\end{array}$ & $-7,8$ & $\begin{array}{c}60, \\
84\end{array}$ & $\begin{array}{c}243, \\
36\end{array}$ \\
\hline 3 & $\begin{array}{c}72- \\
77\end{array}$ & 4 & 75 & $\begin{array}{c}30 \\
0\end{array}$ & $-1,8$ & 3,24 & $\begin{array}{c}12,9 \\
6\end{array}$ \\
\hline 4 & $78-$ & 4 & 81 & 32 & 4,2 & 17,6 & 70,5 \\
\hline
\end{tabular}

F Keterangan :

$\mathrm{Xi} \quad=$ nilai tengah kelas interval

Fi.xi = jumlah data observasi dikali dengan nilai tengah kelas interval

$\mathrm{xi}-\mathrm{x} \quad=$ nilai rata-rata siswa

$\mathrm{SD}=\sqrt{\frac{\sum f i(x i-x)^{2}}{n-1}}=\sqrt{\frac{2586,6}{24}}=\sqrt{107,775}=10,38$

Berdasarkan hasil perhitungan nilai Mean dari data kelas kontrol adalah sebesar 76,8 sedang SD 10,38. untuk mengetahui nilai tertinggi yang dikategorikan sangat baik adalah dengan menjumlahkan nilai mean dan standar deviasi $76,8+3.0+10,38=90,18$. Hal ini berarti nilai perolehan siswa yang dikatakan sangat baik apabila memperoleh nilai diatas 90,18. Sedangkan untuk mengetahui nilai perolehan siswa yang dikategorikan baik $76,8+1.5+10,38=88.68$. Perolehan nilai yang dikatakan sedang $76,8+0.5+10,38=87.68$. Perolehan nilai yang dikategorikan kurang $76,8-0.5-10,38=$ 65.95. sedangkan perolehan nilai yang dikategorikan sangat kurang adalah $76,8-1.5-10,38=64,92$. hal ini berarti nilai perolehan siswa yang dikatakan sangat kurang apabila memperoleh nilai kurang dari 64,92.

Data Rincian Klasifikasi Hasil Belajar PKn Kelas Eksperimen

\begin{tabular}{|c|c|c|c|}
\hline No. & Nilai & $\begin{array}{c}\text { Kriteria } \\
\text { Penilaian }\end{array}$ & $\begin{array}{c}\text { Jumlah } \\
\text { Siswa }\end{array}$ \\
\hline 1. & $\geq 90,18$ & Sangat Baik & 1 \\
\hline 2. & $\geq 88.68$ & Baik & 2 \\
\hline 3. & $\geq 87.68$ & Cukup & 17 \\
\hline 4. & $\leq 65.95$ & Kurang & 4 \\
\hline 5. & $\leq 64,92$ & $\begin{array}{c}\text { Sangat } \\
\text { Kurang }\end{array}$ & 1 \\
\hline \multicolumn{3}{|c|}{ Jumlah } & 25 \\
\hline
\end{tabular}

Berdasarkan data diatas diketahui jumlah siswa yang memperoleh hasil belajar sangat baik berjumlah 1 orang, Baik berjumlah 2, cukup berjumlah 17, kurang berjumlah 4, sangat kurang berjumlah 1.

\section{- Uji Prasyarat Analisis}

Sebelum lanjut ke uji hipotesis harus melalui dua uji yaitu uji normalitas dan uji homogenitas, uji homogenitas peneliti menggunakan rumus uji $\mathrm{F}$ sedangkan uji normalitas peneliti menggunakan rumus Chi-kuadrat, tujuanya yaitu untuk mengetahui apakah varian kedua sampel tersebut homogen atau tidak. Maka baru bisa lanjut ke uji hipotesis.

Nilai kelas eksperimen dapat dikatakan homogen jika nilai $F_{\text {hitung }}$ lebih kecil dari nilai $F_{\text {tabel }}$ $\left(F_{\text {hitung }}<F_{\text {tabel }}\right)$ pada taraf signifikan $5 \%$ dari data diatas dapat diperoleh nilai $F_{\text {tabel }}=2,04$ dan $F_{\text {hitung }}=1,24$. Jadi $F_{\text {hitung }}<F_{\text {tabel }}$. Berdasarkan kriteria yang ada, jika $F_{\text {hitung }<}$ $F_{\text {tabel }}$ maka kelas kontrol dan kelas eksperimen dapat dikatakan memiliki varians yang sama, yang menandakan kedua kelas homogen pada taraf signifikan $5 \%$.

- Uji Homogenitas 
Uji homogenitas dilakukan untuk menyelidiki apakah data kelas kontrol dan kelas eksperimen pada kedua subjek mempunyai varians yang sama atau tidak.

Berdasarkan hasil perhitungan uji homogenitas pada kedua kelas diperoleh bahwa $\mathrm{F}_{\text {hitung }}=1.24$ dan $\mathrm{F}_{\text {tabel }}$ $=2,04$ pada taraf signifikan $\alpha=0,05$ (5\%) dengan derajat kebebasan pembilang 24 dan derajat kebebasan penyebut 27. Data tersebut menunjukkan bahwa $\mathrm{F}_{\text {hitung }<}$ $\mathrm{F}_{\text {tabel. }}$ Berdasarkan kriteria yang ada, jika $\mathrm{F}_{\text {hitung }}<\mathrm{F}_{\text {tabel }}$ maka kedua kelas dikatakan homogen pada taraf signifikan $5 \%$. Dengan demikian, data kemampuan kelas kontrol dan hasil belajar PKn siswa kelas eksperimen dinyatakan homogen. (perhitungan selengkapnya dapat dilihat pada lampiran 29).

\section{- Uji Normalitas}

Sebelum dilakukan uji hipotesis terlebih dahulu dilakukan uji normalitas untuk menentukan statistik apa yang harus digunakan dalam pengujian hipotesis. Uji normalitas data hasil belajar dilakukan dengan cara membandingkan harga $\left(\mathrm{X}^{2}\right.$ hitung $)$ dengan $\left(\mathrm{X}^{2}\right.$ tabel $)$ pada taraf signifikan $5 \%$.

Pasangan hipotesis yang akan diuji adalah sebagai berikut :

$\mathrm{H}_{\mathrm{o}}$ : data berasal dari populasi yang berdistribusi normal

$\mathrm{H}_{\mathrm{a}}$ : data berasal dari populasi yang tidak berdistribusi normal

\section{- Uji Normalitas Kelompok Eksperimen}

Uji normalitas yang digunakan adalah uji chi kuadrat. Dari hasil pengujian untuk kelas eksperimen diperoleh nilai $X^{2}$ hitung $=5,1$ (lampiran 25) dan dari tabel nilai kritis uji chi khuadrat diperoleh nilai $X^{2}$ tabel dengan taraf signifikan $5 \%$ dan $\mathrm{dk}=$ jumlah kelas $-1=6$ $-1=5$ di dapat harga $\mathrm{X}^{2}$ tabel $=11,070$. Karena $X^{2}$ hitung kurang dari $X^{2}$ tabel $(5,1<11,070)$ maka $\mathrm{H}_{\mathrm{a}}$ diterima, artinya data yang terdapat pada kelas eksperimen berasal dari populasi yang berdistribusi normal. (Lampiran 25)

\section{- Uji Normalitas Kelas Kontrol}

Uji normalitas yang digunakan adalah uji Chi kuadrat. Dari hasil pengujian untuk kelompok kontrol diperoleh nilai $X^{2}$ hitung $=5,144$ (lampiran 23) dan dari tabel nilai kritis uji chi kuadrat diperoleh nilai $X^{2}$ tabel pada taraf signifikan $5 \%$ dan $\mathrm{dk}=$ jumlah kelas $-1=6-1$ $=5$ didapat harga $X^{2}$ tabel $=11,070$. Karena $X^{2}$ hitung kurang dari $X^{2}$ tabel $(5,144<11.070)$ maka $\mathrm{H}_{\mathrm{a}}$ diterima, artinya data yang terdapat pada kelas kontrol berasal dari populasi yang berdistribusi normal.

Untuk lebih jelasnya hasil dari uji normalitas antara kelas eksperimen dan kelas kontrol dapat dilihat pada tabel berikut:

$\begin{array}{ccccc}\text { Rekapitulasi Hasil Perhitungan Uji Normalitas } \\ \text { Kelas } & \begin{array}{c}\text { Jumlah } \\ \text { sampel }\end{array} & \begin{array}{l}\boldsymbol{X}^{2} \\ \text { hitung }\end{array} & \begin{array}{l}\boldsymbol{X}^{2} \\ \text { tabel } \\ \text { a= }\end{array} & \text { Kesimpulan } \\ & & & \begin{array}{l}\text { o,o5 } \\ \text { Konl }\end{array} \\ \text { Eksperimen } & 25 & 5,1 & 11.070 & \text { Normal } \\ \text { Kontrol } & 28 & 5,144 & 11.070 & \text { Normal }\end{array}$

Karena $X^{2}$ hitung pada kedua kelas kurang dari $X^{2}$ tabel maka dapat disimpulkan bahwa data populasi kedua kelompok berdistribusi normal.

\section{- Uji Hipotesis}

\section{Merumuskan Ha dan Ho}

Ho : Tidak terdapat perbedaan pengaruh antara model pembelajaran inkuiri terbimbing dengan model pembelajaran inkuiri training terhadap hasil belajar siswa.

$\mathrm{Ha}$ : Terdapat perbedaan pengaruh antara model pembelajaran inkuiri terbimbing dengan model pembelajaran inkuiri training terhadap hasil belajar siswa.

Ha $: \mu_{1}=\mu_{2}$

Ho : $\mu_{1}=\mu_{2}$

\section{Membuat Tabel Kerja}

\begin{tabular}{|c|c|c|}
\hline No. & $\mathbf{X}_{1}$ & $\mathbf{X}_{2}$ \\
\hline 1 & 60 & 50 \\
\hline 2 & 85 & 65 \\
\hline 3 & 65 & 75 \\
\hline 4 & 80 & 60 \\
\hline 5 & 65 & 75 \\
\hline 6 & 85 & 55 \\
\hline 7 & 90 & 70 \\
\hline 8 & 95 & 65 \\
\hline 9 & 70 & 80 \\
\hline 10 & 85 & 85 \\
\hline 11 & 85 & 75 \\
\hline 12 & 75 & 75 \\
\hline 13 & 75 & 60 \\
\hline 14 & 80 & 60 \\
\hline 15 & 70 & 55 \\
\hline 16 & 65 & 70 \\
\hline 17 & 90 & 85 \\
\hline 18 & 75 & 55 \\
\hline 19 & 80 & 75 \\
\hline 20 & 70 & 60 \\
\hline 21 & 75 & 70 \\
\hline 22 & 70 & 65 \\
\hline 23 & 80 & 80 \\
\hline 24 & 85 & 50 \\
\hline 25 & 65 & 80 \\
\hline 26 & & 65 \\
\hline 27 & & 75 \\
\hline 28 & & 75 \\
\hline Jumlah & $\begin{array}{c}\sum=1920 \\
n_{1}=25\end{array}$ & $\begin{array}{c}\sum=1910 \\
n_{2}=28\end{array}$ \\
\hline $\begin{array}{l}\text { Rata- } \\
\text { rata }\end{array}$ & $X_{1}=76,8$ & $\begin{array}{l}X_{2}= \\
68.21\end{array}$ \\
\hline Varians & $\begin{array}{c}\mathrm{S}_{1}{ }^{2}= \\
330.21\end{array}$ & $\begin{array}{c}S_{2}{ }^{2}= \\
266.005\end{array}$ \\
\hline
\end{tabular}

Cara mencari $\mathrm{X}_{1}$

Cara mencari $\mathrm{X}_{2}$

$\mathrm{Me}=\frac{1920}{25}=76.8$

$\mathrm{Me}=\frac{1910}{28}=68.2$

Cara mencari $\mathrm{S}_{1}{ }^{2}$

Cara mencari $\mathrm{S}_{2}{ }^{2}$

$\mathrm{S}^{2}=\frac{\sum(x i-x)^{\mathrm{I}}}{n-1}=\frac{7925}{24}=330.21$

$\mathrm{S}^{2}=\frac{\sum(x i-x)^{2}}{n-1}=\frac{718.142}{27}=266.005$

Memasukkan Data Kedalam Rumus

Diketahui :

Keterangan :

$\mathrm{X} 1=76,8$

$\mathrm{t}=$ nilai $\mathrm{t}$ yang dihitung

$\mathrm{X}_{2}=68.21$

$\mathrm{X}_{1}=$ nilai rata-rata kelas eksperimen

$\mathrm{S}_{1}{ }^{2}=330.21$

$\mathrm{X}_{2}=$ nilai rata-rata kelas kontrol

$\mathrm{S}_{2}{ }^{2}=266.005$

$\mathrm{S}_{1}{ }^{2}=$ Varians kelas eksperimen

$\mathrm{n}_{1}=25$

$\mathrm{S}_{2}{ }^{2}=$ Varians kelas kontrol 
$\mathrm{n}_{2}=28$

$\mathrm{n}_{1}=$ Jumlah anggota kelaseksperimen

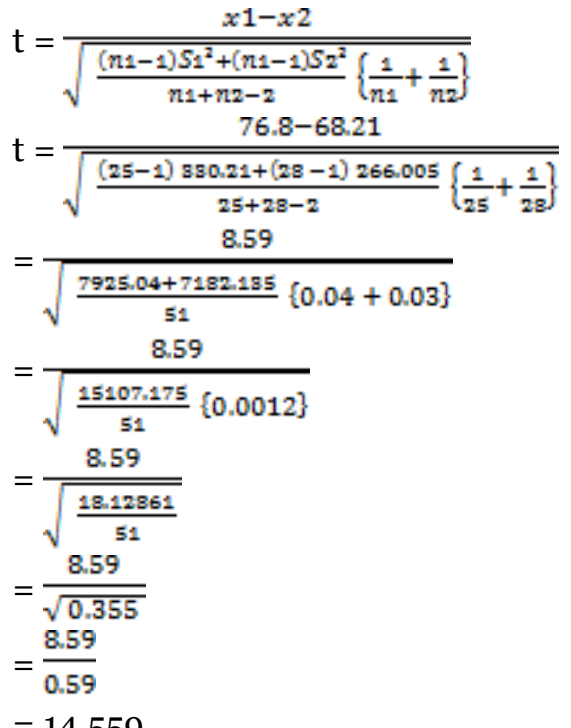

Menentukan t-tabel

Dalam menentukan $t_{\text {tabel }}$ terlebih dahulu akan ditentukan derajat kebenarannya. Dengan rumus: $\mathrm{dk}=$ $\mathrm{n}_{1}+\mathrm{n}_{2}-2=25+28-2=51$. Dengan dk 51 dan taraf signifikan $(\alpha)$ o,05 (5\%) maka $t_{\text {tabel }}=2,000$

Membandingkan Antara $\boldsymbol{T}_{\text {hitung }}$ Dengan $\boldsymbol{T}_{\text {tabel }}$

Selanjutnya $T_{\text {hitung tersebut dibandingkan }}$ dengan $T_{\text {tabel, }}$, dimana $T_{\text {hitung }}=14.559$ dan $T_{\text {tabel }}=2,000$

\section{Kesimpulan}

Harga $T_{\text {hitung }}$ lebih besar dari $T_{\text {tabel}},(14.559 \geq$ 2,000) sehingga Ho ditolak dan Ha diterima. Jadi terdapat perbedaan pengaruh antara model pembelajaran Inkuiri Terbimbing dengan model pembelajaran Inkuiri Training terhadap hasil belajar PKn siswa kelas XI SMAN 2 Woha Tahun Pelajaran 2016/2017.

\section{Pembahasan}

Pembelajaran yang paling baik adalah pembelajaran yang melibatkan peserta didik agar mereka mampu mengajarkan materi yang diajarkan kepada orang lain. Peserta didik yang dapat mengajarkan materi yang disampaikan oleh pendidik atau guru kepada orang lain berarti dia sudah memahami dan menguasai materi tersebut.

Berdasarkan kelas kontrol dan kelas eksperimen siswa, diperoleh nilai rata-rata untuk hasil belajar kelas kontrol sebesar 68.21 dengan menggunakan model pembelajaran inkuiri training sedangkan untuk hasil belajar kelas eksperimen diperoleh nilia rata-rata 76.8 dengan menggunakan model pembelajaran inkuiri terbimbing. Dengan demikian menunjukkan bahwa terdapat perbedaan dari penggunaan 2 model pembelajaran tersebut, yang menunjukan bahwa pembelajaran dengan menggunakan model pembelajaran inkuiri terbimbing lebih efektif dari pada pembelajaran dengan menggunakan model pembelajaran inkuiri training.

Inkuiri terbimbing merupakan suatu cara yang efektif untuk membuat variasi suasana pola pembelajaran kelas. Pembelajaran inkuiri terbimbing merupakan pembelajaran kelompok dimana siswa diberi kesempatan untuk berfikir mandiri dan saling membantu dengan teman yang lain. Pembelajaran inkuiri terbimbing membimbing siswa untuk memiliki tanggung jawab individu dan tanggung jawab dalam kelompok atau pasangannya (Ambasari,2013:83).

Dalam pembelajaran dengan model inkuiri terbimbing peran utama guru sebagai motifator dan fasilitator, sehinnga dapat menciptakan kondisi dimana siswa dihadapkan pada suatu masalah. Pada proses pemebelajaran guru dapat menyediakan dan sebagai pentujuk. Perumusan masalah dilontarkan oleh guru, dalam bentuk pertanyaan atau pernyataan, konsep harus ditemukan oleh siswa itu sendiri. Pada tahap awal bimbingan lebih banyak diberikan, dan sedikit demi sedikit dikurangi sesuai dengan perkembangan siswa (Asminah, 2010:40).

Jadi inkuiri terbimbing merupakan model pembelajaran yang dimana dalam proses kegiatan belajar dan mengajar guru membimbing dan mengarahkan siswa dengan mengajukan permasalahan, dan kemudian guru bersama siswa mencari pemecahan masalah yang telah di ajukan oleh guru kepada siswa dengan mengadakan penelitian secara mandiri siswa akan menemukan konsep dari permasalahan dalam pembelajarannya, kemudian akan menyimpulkan hasil penelitian serta pengamatannya dan akan di sampaikan oleh setiap siswa kepada siswa lainnya. Dengan demikian siswa akan terlibat aktif dan dapat menemukan makna dalam proses belajar mengajar yang dilakukannya.

Perbedaan pengaruh dalam melakukan penelitian eksperimen ini peneliti tentu sangat berharap bahwa perlakuan yang dilakukan yakni penggunaan model pembelajaran inkuiri terbimbing dengan model pembelajaran inkuiri training akan mendapatkan hasil belajar yang positif sehinga pada pengujian hipotesis yang dilakukan dengan pengujian kelas eksperimen taraf signifikan 5\%, maka nila "t" pada tabel yaitu 2,000 dan " $\mathrm{t}$ " hasil belajar analisis adalah $\mathbf{1 4 . 5 5 9}$ oleh karena itu "thitung" hasil belajar analisis lebih besar dari nilai t-tabel. Dari hasil tersebut berarti hipotesis yang berbunyi: "terdapat perbedaan pengaruh antara model pembelajaran inkuiri terbimbing dengan model pembelajaran inkuiri training terhadap hasil belajar PKn siswa kelas XI SMAN 2 Woha Bima Tahun Pelajaran 2016/2017" diterima.

\section{SIMPULAN DAN SARAN}

\section{Kesimpulan}

Dari hasil penelitian yang telah dilakukan maka dapat disimpulkan bahwa terdapat pengaruh antara model pembelajaran inkuiri terbimbing dengan model pembelajaran inkuiri training terhadap hasil belajar PKn siswa kelas XI SMAN 2 Woha Bima Tahun Pelajaran 2016/2017. Hal ini ditunjukkan oleh hasil perhitungan dengan menggunakan rumus t-tes, maka didapatkan $\mathrm{T}_{\text {hitung }}=14.559$ dan $T_{\text {tabel }}$ dengan $\mathrm{dk}=\mathrm{n}_{1}+\mathrm{n}_{2}$ $-2=25+28-2=51$. Dengan dk 51 dan taraf signifikan $5 \%$ maka $\mathrm{t}_{\text {tabel }}=2$,ooo. Maka t-hitung $>\mathrm{t}$-tabel yaitu (14.559 > 2,000). Artinya Ho ditolak dan Ha diterima.

\section{Saran}

Mengingat pentingnya pendekatan pembelajaran dalam suatu pembelajaran dan sehubungan dengan hasil penelitian ini peneliti menyarankan sebagai berikut:

- Guru dapat melaksanakan proses pembelajaran dengan menggunakan model pembelajaran inkuiri terbimbing dan model pembelajaran inkuiri training. 
- Peneliti selanjutnya, hendaknya sel alu mengkaji, menemukan dan mendesain strategi pembelajaran yang akan lebih menuntut peserta didik untuk bisa mengaktualisasikan keterampilan.

- Pemecahan masalah yang diberikan hendaknya disesuaikan dengan kemampuan rata-rata dari peserta didik dan juga guru harus selalu mengawasi karena dikhawatirkan peserta didik salah dalam memahami konsep.

- Pembelajaran dengan menggunakan model pembelajaran inkuiri terbimbing dan model pembelajaran inkuiri training perlu terus dikembangkan dan diaplikasikan karena dapat meningkatkan kemampuan berpikir peserta didik. 